\title{
Illegal hunting in Jordan: using social media to assess impacts on wildlife
}

Ehaв Eid and RAmZi Handal

\begin{abstract}
This study is the first to provide data on the extent of illegal hunting practices in Jordan using posts on social media. During January 2015-January 2016 photographs from seven hunter groups on Facebook recorded the killing of 4,707 native animals of 59 species, of which birds constituted the majority, followed by mammals and reptiles. Flouting of Jordanian laws was widespread, with daily bag limits exceeded on many occasions, and in the case of chukar partridge Alectoris chukar, the most popular quarry, some hunters exceeded the limit by $3,000 \%$. Of even greater concern, a total of 34 species with special protection under Jordanian law were killed, and the hunting of large mammals, especially ibex Capra nubiana and gazelles (Gazella spp.), with already depleted populations, was particularly excessive. It also appeared that a significant number of gazelles were shot by unlicensed hunters from Arabian Gulf countries. Overall, the survey indicates an alarming picture of overhunting of threatened species and ineffective enforcement of hunting laws, despite the efforts of key government and voluntary agencies. We recommend urgent action to address the causes of the problem and to improve the management of hunting through better collaboration, mobilization of resources and awareness raising.
\end{abstract}

Keywords Facebook, hunting, illegal, impact, Jordan, social media, wildlife

\section{Introduction}

7 he Government of Jordan recognized the importance of ing law was issued by the Ministry of Agriculture. Since then, this law has been revised and amended to meet changing needs, and several institutions have been established to manage and regulate hunting. In 1956 the concept of game species was first introduced and in 1966 regulations on guns used for hunting were issued. In the same year, the Royal Jordanian Hunting Club was reborn as the Royal Society for the Conservation of Nature (Fitter, 1967) and given a de facto role in hunting control. At the time, all hunting

EHAB EID (Corresponding author) The Royal Marine Conservation Society of Jordan, P.O. Box 831051, Abdel Aziz El Thaalbi Street, Building no. 7, Shmesani 11183, Amman, Jordan. E-mail eha_jo@yahoo.com

Ramzi Handal Jordan's Outdoor Sport Association, Shmesani, Amman, Jordan

Received 27 September 2016. Revision requested 21 October 2016.

Accepted 22 November 2016. First published online 4 May 2017. and shooting was forbidden without a license (which cost JOD 5 per year) and hunting seasons and bag limits for all game species were set by the Royal Society for the Conservation of Nature committee (Fitter, 1967). In addition, the use of automatic weapons, nets and traps, and mechanical vehicles and spotlights for hunting were prohibited. In 1973 the government amended the Agricultural Law to incorporate a Wildlife Conservation Law and delegated the Royal Society to implement this (Amr et al., 2004). Under this Law the Royal Society's previous de facto role in hunting control became official and it was given authority to issue and administer hunting licences and impose fines for non-compliance with the hunting laws.

The Royal Department for Environmental Protection was established in 2006 to improve the quality of Jordan's environment through proper and effective enforcement of environmental legislation, enhancing cooperation with and between relevant authorities, and increasing national support and advocacy for environmental issues. Since its establishment, the agency has worked cooperatively with the Royal Society for the Conservation of Nature and has had some success in preventing violations against wildlife, with a total of 354 hunting violations registered and handled during 2009-2014 (Ministry of Environment, 2016). In 2014 the Jordan Outdoor Sport Association was created as a non-profit hunters' association, to spread awareness amongst hunters and other stakeholders about sustainable hunting in Jordan. Since its establishment the Association has carried out release programmes in wilderness areas for two popular game species, chukar partridge Alectoris chukar and sand partridge Ammoperdix heyi. These are intended to supplement existing wild populations and meet hunters' needs more sustainably (R. Handal, pers. obs.).

Currently, hunting is covered by three laws: Agricultural Law No. 13 (2015), the Aqaba Region Authority Law No. 32 (2000), and the Law of Environmental Protection No. 1 (2003) (Amr et al., 2004). These laws have a wide range of clauses for protecting wild animals, including hunting regulations, for ensuring cooperation between nongovernmental and governmental agencies, and for assigning responsibilities for enforcement and the distribution of available funds among agencies. There are also articles defining the level of penalties for violations of these laws, based on detailed appendices in regulation No. 34 (2003) of the Agriculture Law. Hunting of species on Appendix I is punishable by imprisonment for 4 months and a fine of JOD 1,000, on Appendix II by imprisonment for 3 months 
and a fine of JOD 1,00o, and on Appendix III by imprisonment for 1 month and a fine of JOD 100 (FAOLEX, 2015).

Although hunting is a socially acceptable practice in Jordan (at least for the majority), there is concern about increasing illegal hunting and its impact on individual species. Prominent hunters have estimated the number of unlicensed hunters to be 5,000-10,000 (RSCN, 2005; R. Handal, pers. obs., 2015) but the number could be up to C. 16,000 (i.e. four times the number of licensed hunters; RSCN, 2005). There are, however, few data on the scale of illegal hunting and its effect on game and other species. We therefore attempt here to establish the extent of the problem and to discuss the conservation implications for globally threatened species and species protected by Jordanian law. Illegal hunting in Jordan is poorly documented by the responsible authorities because of problems with species identification, and we therefore used the visibility of hunting on social media to obtain data on the number and species hunted.

\section{Methods}

Daily investigations of seven hunting groups active on Facebook were carried out during January 2015-January 2016 (13 months). These groups were accessible to anybody following a join request. We did not visit the personal pages of hunters, collect any personal information or interact with the people posting photographs. Only photographs uploaded to the groups' pages were collected, and stored on an encrypted drive. All posts with photographs of hunted species were downloaded within a day of being posted. A total of 1,251 photographs were downloaded and screened to remove duplicates and any in which there was uncertainty about the source and/or the species killed. Such uncertainties became evident from an examination of vehicle numbers present in the photographs, from comments that appeared with each photograph, and/or from images of the hunters. After duplicates and photographs with other anomalies (such as a low resolution) were omitted, a total of 606 photographs remained. These were examined in detail to determine the species hunted and the number of each species killed.

\section{Results}

In the 606 photographs a total of 4,707 individuals of 59 species were hunted in the wild over the study period. The majority were birds $(n=3,920,84 \%)$, followed by mammals $(785,16 \%)$ and reptiles $(2,<1 \%$; Table 1$)$. Five species of mammals categorized as Vulnerable on the IUCN Red List (IUCN, 2016) were recorded (Nubian ibex Capra nubiana, goitered gazelle Gazella subgutturosa, dorcas gazelle Gazella dorcas, mountain gazelle Gazella gazella, marbled polecat Vormela peregusna), along with two Vulnerable bird species (Asian houbara Chlamydotis macqueenii, turtle dove Streptopelia turtur), two Endangered bird species (saker falcon Falco cherrug, steppe eagle Aquila nipalensis), and a Vulnerable reptile species (Egyptian spiny-tailed lizard Uromastyx aegyptia).

The chukar partridge was the most hunted species, with a total of 1,503 kills recorded, followed by the common quail Coturnix coturnix (849) and the rock dove Columba livia (632). The cape hare Lepus capensis was the most commonly hunted species of mammal, with a total of 438 kills, followed by the Nubian ibex (115) and wild boar Sus scrofa (40).

Of the 59 species killed by hunters, 36 are protected under Jordanian law and were therefore hunted illegally. These include nine species listed in Appendix I of Agriculture Law No. 13 (7 mammals and 2 birds), 15 species on Appendix II (7 mammals and 8 birds) and 12 species on Appendix III (1 mammal, 1 reptile and 10 birds).

Many hunters also appear to be flouting the regulations on bag limits. These limits specify the number of kills allowed for a given species in a single day or period by a single hunter; these are announced annually by the Ministry of Agriculture following recommendations provided by the Wildlife Committee. Table 2 provides a comparison of the legal bag limits over the study period for four bird species that can be legally hunted with the maximum number of kills revealed in single photographs posted by hunters on Facebook. Assuming that the number of hunters that appear in each photograph (including the photographer) represent all the hunters involved in the display of kills, and that all the birds in each photograph were killed on the same day, then bag limits for these species were considerably exceeded. In the case of the chukar and sand partridges, for example, the bag limits on the days the photographs were taken were exceeded by $>3,000$ and $>1,000 \%$, respectively.

\section{Discussion}

High species diversity in Jordan is a result of its location at the junction of the African, Oriental and Palaearctic faunal regions (Amr et al., 2004). The Kingdom is known to support 83 species of mammals (Amr, 2012), 406 species of birds (Eid \& Qaneer, 2013), and 103 species of reptiles and amphibians (Disi et al., 2014). Threats to species in Jordan have increased since the beginning of the 2oth century, when machine guns and vehicles for hunting were first introduced (Qumsiyeh et al., 1996). This, together with growth of the human population, habitat loss and the growing popularity of hunting amongst urban populations, has caused the extinction of the Arabian oryx Oryx leucoryx (Nelson, 1973; Fitter, 1984; Lamb, 1984; Hatough \& Al-Eisawi, 1987; Qumsiyeh, 1996), roe deer Capreolus capreolus (Eid \& Ananbeh, 2009), and the Arabian leopard 
TABLE 1 Animal species and numbers hunted in Jordan during January 2015-January 2016, as recorded from photographs posted on Facebook by hunters' groups, with their protected status in Jordan (according to the Ministry of Agriculture), category on the IUCN Red List (2016), range of hunting bag size in photographs, total number killed, and whether species can be legally hunted.

\begin{tabular}{llllll}
\hline & Protected status & IUCN Red & Range of & Total number & Legally \\
Species & in Jordan & List status & number killed & killed & hunted?
\end{tabular}

Class Mammalia, Order Artiodactyla

Family Suidae

Wild boar Sus scrofa

Family Bovidae

Nubian ibex Capra nubiana

Dorcas gazelle Gazella dorcas

Mountin gazelle Gazella gazella

Goitered gazelle Gazella subgutturosa

Family Canidae

Golden jackal Canis aureus

Wolf Canis lupus

Red fox Vulpes vulpes

Family Felidae

Caracal Caracal caracal

Family Herpestidae

Egyptian mongoose Herpestes ichneumon

Family Hyaenidae

Striped hyaena Hyaena hyaena

Family Hystricidae

Indian crested porcupine Hystrix indica

Family Leporidae

Cape hare Lepus capensis

Family Mustelidae

Stone marten Martes foina

European badger Meles meles

Marbled polecat Vormela peregusna

Family Procaviidae

Rock hyrax Procavia capensis
List status ${ }^{\star}$

number killed

hunted?

\begin{tabular}{|c|c|c|c|}
\hline & LC & $1-5$ & 40 \\
\hline Appendix I & VU & $1-5$ & 115 \\
\hline Appendix I & VU & 1 & 2 \\
\hline Appendix I & VU & 1 & 1 \\
\hline Appendix I & VU & $1-10$ & 23 \\
\hline Appendix I & LC & $1-2$ & 3 \\
\hline \multirow{2}{*}{ Appendix I } & LC & 1 & 1 \\
\hline & LC & $1-3$ & 18 \\
\hline Appendix I & LC & 1 & 1 \\
\hline Appendix II & LC & 1 & 1 \\
\hline Appendix II & NT & 1 & 27 \\
\hline Appendix II & LC & $1-2$ & 32 \\
\hline Appendix III & LC & $1-28$ & 438 \\
\hline Appendix II & LC & 1 & 1 \\
\hline Appendix II & LC & $1-2$ & 30 \\
\hline Appendix II & LC & 1 & 2 \\
\hline Appendix II & LC & $1-8$ & 37 \\
\hline
\end{tabular}

Class Reptilia

Family Agamidae

Egyptian spiny-tailed lizard Uromastyx aegyptia

Appendix III

VU

2

Class Aves

Family Accipitridae

Eurasian sparrowhawk Accipiter nisus

Steppe eagle Aquila nipalensis

Steppe buzzard Buteo buteo

Long-legged buzzard Buteo rufinus

Western marsh harrier Circus aeruginosus

Black-winged kite Elanus caeruleus

Family Anatidae

Northern pintail Anas acuta

Northern shoveler Anas clypeata

Blue-winged teal Anas discors

Mallard Anas platyrhynchos

Garganey Anas querquedula

Family Ardeidae

Purple heron Ardea purpurea

Family Burhinidae

Eurasian stone curlew Burhinus oedicnemus

Family Caprimulgidae

Nightjar Caprimulgus europaeus

Family Cerylidae

Pied kingfisher Ceryle rudis
Appendix II LC

Appendix II

Appendix II

Appendix II

Appendix II

EN

LC

LC

LC

LC

LC

LC

LC

LC

LC

Appendix III LC

Appendix III LC

LC

Appendix III

LC

Appendix III

LC
No

Yes

No

No

No

No

No

No

No

No

No

No

No

No

No

No

No

No

No

No

No

No

No

No

No

No

No

No

No

No

No

No

No 
Table 1 (Cont.)

\begin{tabular}{|c|c|c|c|c|c|}
\hline Species & $\begin{array}{l}\text { Protected status } \\
\text { in Jordan }\end{array}$ & $\begin{array}{l}\text { IUCN Red } \\
\text { List status }\end{array}$ & $\begin{array}{l}\text { Range of } \\
\text { number killed }\end{array}$ & $\begin{array}{l}\text { Total number } \\
\text { killed }\end{array}$ & $\begin{array}{l}\text { Legally } \\
\text { hunted? }\end{array}$ \\
\hline \multicolumn{6}{|l|}{ Family Charadriidae } \\
\hline Spur-winged plover Vanellus spinosus & & LC & $1-2$ & 3 & No \\
\hline \multicolumn{6}{|l|}{ Family Ciconiidae } \\
\hline White stork Ciconia ciconia & Appendix III & LC & $1-2$ & 4 & No \\
\hline Black stork Ciconia nigra & Appendix III & $\mathrm{LC}$ & 1 & 1 & No \\
\hline \multicolumn{6}{|l|}{ Family Columbidae } \\
\hline Rock dove Columba livia & & $\mathrm{LC}$ & $1-67$ & 632 & Yes \\
\hline Laughing dove Spilopelia senegalensis & & $\mathrm{LC}$ & $1-86$ & 390 & No \\
\hline Collared dove Streptopelia decaocto & & LC & $3-92$ & 209 & Yes \\
\hline Turtle dove Streptopelia turtur & & VU & $5-21$ & 72 & Yes \\
\hline \multicolumn{6}{|l|}{ Family Corvidae } \\
\hline Eurasian jay Garrulus glandarius & & LC & 1 & 1 & No \\
\hline \multicolumn{6}{|l|}{ Family Falconidae } \\
\hline Saker falcon Falco cherrug & Appendix I & EN & 1 & 1 & No \\
\hline Common kestrel Falco tinnunculus & Appendix II & $\mathrm{LC}$ & 1 & 2 & No \\
\hline \multicolumn{6}{|l|}{ Family Glareolidae } \\
\hline Cream-coloured courser Cursorius cursor & Appendix III & LC & $1-2$ & 3 & No \\
\hline \multicolumn{6}{|l|}{ Family Gruidae } \\
\hline Common crane Grus grus & Appendix III & LC & $1-6$ & 30 & No \\
\hline \multicolumn{6}{|l|}{ Family Otididae } \\
\hline Houbara bustard Chlamydotis undulata & Appendix I & VU & 1 & 1 & No \\
\hline \multicolumn{6}{|l|}{ Family Phasianidae } \\
\hline Chukar partridge Alectoris chukar & & $\mathrm{LC}$ & $1-76$ & 1503 & Yes \\
\hline Sand partridge Ammoperdix heyi & & $\mathrm{LC}$ & $3-24$ & 39 & Yes \\
\hline Common quail Coturnix coturnix & & $\mathrm{LC}$ & $1-80$ & 849 & Yes \\
\hline Black francolin Francolinus francolinus & Appendix III & $\mathrm{LC}$ & $1-15$ & 34 & No \\
\hline \multicolumn{6}{|l|}{ Family Pteroclididae } \\
\hline Pin-tailed sandgrouse Pterocles alchata & & $\mathrm{LC}$ & 56 & 56 & No \\
\hline \multicolumn{6}{|l|}{ Family Rallidae } \\
\hline Eurasian coot Fulica atra & & $\mathrm{LC}$ & 1 & 1 & Yes \\
\hline Water rail Rallus aquaticus & Appendix III & $\mathrm{LC}$ & 1 & 1 & No \\
\hline \multicolumn{6}{|l|}{ Family Recurvirostridae } \\
\hline Black-winged stilt Himantopus himantopus & & $\mathrm{LC}$ & 1 & 1 & No \\
\hline \multicolumn{6}{|l|}{ Family Scolopacidae } \\
\hline Eurasian woodcock Scolopax rusticola & & $\mathrm{LC}$ & 2 & 2 & No \\
\hline \multicolumn{6}{|l|}{ Family Strigidae } \\
\hline Eagle owl Bubo bubo & & LC & 2 & 2 & No \\
\hline \multicolumn{6}{|l|}{ Family Sturnidae } \\
\hline Tristram's starling Onychognathus tristramii & & LC & 1 & 1 & No \\
\hline Common starling Sturnus vulgaris & & $\mathrm{LC}$ & 1 & 1 & No \\
\hline \multicolumn{6}{|l|}{ Family Turdidae } \\
\hline Mistle thrush Turdus viscivorus & & LC & 4 & 4 & Yes \\
\hline
\end{tabular}

${ }^{\star}$ LC, Least Concern; NT, Near Threatened; VU, Vulnerable, EN, Endangered

Panthera pardus nimr (Amr, 2012), and several others are seriously threatened, including the Nubian ibex, gazelle species (Amr, 2012) and the Asian houbara (Eid \& Qaneer, 2013). The species that have declined in Jordan during the past 3 centuries have been mainly of the orders Artiodactyla and Carnivora (Qumsiyeh et al., 1994, 1996).

Much of the existing academic research on Facebook has focused on identity presentation and privacy concerns (Gross \& Acquisti, 2005; Stutzman, 2006) and there has been limited research using Facebook groups as a tool to assess the magnitude of illegal hunting. Hunters join Facebook to create and support virtual groups based on their common interests and to maintain connections with fellow hunters, presenting their hunting achievements and expressing their satisfaction with the sport. Braden (2015) studied illegal recreational hunting in Russia, using the media, government reports, environmental organizations and social media. Essen (2016) followed informal conversations on Facebook to examine illegal hunting in Sweden.

It is clear from the level of Facebook activity monitored during the survey period that hunting is thriving in Jordan. Most of the seven groups studied were posting photographs 
TABLE 2 Comparison of the legal bag limits for four bird species that can be legally hunted and the maximum bag sizes recorded on Facebook during January 2015-January 2016.

\begin{tabular}{llll}
\hline Species & Legal bag limit in 2015 & $\begin{array}{l}\text { Maximum no. in } \\
\text { a single photograph }\end{array}$ & $\begin{array}{l}\text { No. of hunters in each photograph } \\
\text { (including the photographer) }\end{array}$ \\
\hline Chukar partridge & One in each trip on Friday \& Sunday of each week & 76 & 2 \\
Sand partridge & One in each trip on Friday \& Sunday of each week & 24 & 2 \\
Common quail & 15 per day & 80 & 5 \\
Turtle dove & 15 in each trip on Friday \& Sunday of each week & 92 & 2 \\
\hline
\end{tabular}

and information on kills on a regular basis and with increasing frequency through the year. The 4,707 individual animals killed in the 13 months of study is worryingly high, especially as the seven groups are only a small proportion of licensed hunters (4,00o registered by the Royal Society for the Conservation of Nature in 2005) and of the estimated $5,000-10,000$ unlicensed hunters. The overall number of animals killed annually, therefore, is likely to be much higher than the number we recorded in Facebook posts. There is therefore little doubt that hunting is a major factor influencing the decline of wildlife species and undermining the success of conservation efforts in the Kingdom.

Our survey also revealed that hunters are killing species protected under Jordanian law and species categorized as threatened on the IUCN Red List (most of which are also protected under Jordanian law). In total we recorded 34 protected species killed illegally, including two migratory birds of prey, the steppe eagle and saker falcon. The saker was apparently captured for trade with visitors from the Arabian Gulf, as evident from the posted photograph, and the eagle was shot. Both of these species are in serious decline (BirdLife International, 2016a,b). The saker falcon is listed on Appendix II of CITES, which highlights the need to improve the control of border trade. The striped hyaena Hyaena hyaena, categorized as Near Threatened on the IUCN Red List (AbiSaid \& Dloniak, 2015), was also killed in significant numbers, with a total of 27 individuals documented in photographs. It is listed on Schedule II of the Jordanian wildlife protection law (MOA, 2015) and is often hunted for traditional medicinal uses and as a sexual tonic (Aloufi \& Eid, 2016). The high number of ungulates killed is of particular concern. We recorded 115 Nubian ibex, 23 goitered gazelles, two dorcas gazelles and one mountain gazelle in photographs on Facebook. There has been a marked decline of gazelles in Jordan, with an estimated goitered gazelle population of $<100$ individuals (Kiwan et al., 2001). Gazelles remain at risk of extinction in Jordan (Amr, 2012) and will not be able to sustain such high hunting pressure.

Despite the efforts of the Royal Society for the Conservation of Nature and the Royal Department for Environmental Protection, it is evident from our findings that the enforcement of Jordan's hunting laws is no longer effective. We suggest that there are a number of key issues that need to be addressed: (1) the increasing number of licensed and unlicensed hunters in Jordan and the lack of sufficient enforcement officers, especially outside protected areas; (2) poor coordination between the parties involved in the management of hunting (including the hunters themselves); (3) a lack of awareness within local communities of the importance of wildlife and conservation; (4) inconsistent support from government and judicial bodies in upholding the law; and (5) inadequate funding to support the expansion of ranger services and effective patrolling. It is also important to note that some of the hunters operating in Jordan are from the Arabian Gulf, most of whom are probably unlicensed. Of the 23 goitered gazelle carcasses recorded, 10 (43\%) were apparently killed by hunters from the Gulf, with the support of Jordanian guides. In 201313 dorcas gazelles were killed in Wadi Araba by hunters from the Gulf (E. Eid, pers. obs.).

Our findings indicate that the management of hunting in Jordan needs to be reviewed, to develop a much more effective licensing and enforcement system that engages all parties, including hunters' groups and the recently formed Outdoor Sport Association. This needs to be linked to a nationwide awareness campaign highlighting the importance and benefits of managing wildlife in a sustainable way. Under Jordanian law photographs of hunting bags, such as those we documented on Facebook, are not sufficient to convict hunters. Enforcement of laws needs to be enhanced to halt the excessive hunting of both protected and unprotected species in Jordan. As a member of the National Wildlife Committee in Jordan, Outdoor Sport Association will ensure our results are used as a basis for future decisions on permits and bag limits for hunted species.

\section{Acknowledgements}

We thank Chris Johnson for reviewing this article, David Mallon for identifying gazelle species, and Laith Elmoghrabi and Feras Rahahleh for identifying and confirming bird species.

\section{Author contributions}

EE collected data and identified species, analysed the data and wrote the article. $\mathrm{RH}$ collected and analysed data. 


\section{References}

AbiS Aid, M. \& Dloniak, S.M.D. (2015) Hyaena hyaena. The IUCN Red List of Threatened Species 2015: e.T10274A45195080. Http://dx. doi.org/10.2305/IUCN.UK.2015-2.RLTS.T10274A45195080.en [accessed 6 February 2017].

Aloufi, A. \& Eid, E. (2016) Zootherapy: a study from the Northwestern region of the Kingdom of Saudi Arabia and the Hashemite Kingdom of Jordan. Indian Journal of Traditional Knowledge, 15, 561-569.

A mr, Z. (2012) Mammals of Jordan. 2nd edition. United Nations Environment Programme, Amman, Jordan.

Amr, Z.S., Hamidan, N. \& Quatrameez, M. (2004) Nature conservation in Jordan. Denisia, 14, 467-477.

BRADEN, K. (2015) Illegal recreational hunting in Russia: the role of social norms and elite violators. Eurasian Geography and Economics, 55, 457-490.

Birdife International (2016a) Aquila nipalensis. The IUCN Red List of Threatened Species 2016: e.T22696038A93540565. Http://dx. doi.org/10.2305/IUCN.UK.2016-3.RLTS.T22696038A93540565.en [accessed 1 November 2016].

Birdife International (2016b) Falco cherrug. The IUCN Red List of Threatened Species 2015: e.T22696495A90562101. Http://dx.doi. org/10.2305/IUCN.UK.2016-3.RLTS.T22696495A90562101.en [accessed 1 November 2016].

Disi, A.M., Amr, Z.S. \& Hamidan, N. (2014) Diversity, threats and conservation of the terrestial and freshwater herpetofauna of Jordan. Russian Journal of Herpetology, 21, 221-233.

Eid, E. \& AnAnbeh, Y. (2009) Assessment of the release program of the European roe deer Capreolus capreolus (Cetartiodactyla: Cervidae) at Ajloun Nature Reserve, Jordan. Journal of Threatened Taxa., 1, 323-326.

Eid, E. \& QAneer, T. (2013) Introduction. In The Royal Society for the Conservation of Nature, 2013, State of Jordan's Birds Report, pp. 2-3. The Royal Society for the Conservation of Nature, Amman, Jordan.

Essen, E.V. (2016) In the gap between legality and legitimacy: illegal hunting in Sweden as a crime of dissent. $\mathrm{PhD}$ thesis. Swedish University of Agricultural Sciences, Uppsala, Sweden.

FAOLEX (2015) Legislative Database of FAO Legal Office. Http://www. fao.org/faolex/en/ [accessed 8 March 2017].

Fitter, M. (1967) New hope for wildlife in Jordan. Oryx, 9, 35-38.

Fitter, R. (1984) Operation Oryx-the success continues. Oryx, 18, 136-137.
Gross, R. \& Acquisti, A. (2005) Information revelation and privacy in online social networks (the Facebook case). Proceedings of the 2005 ACM Workshop on Privacy in the Electronic Society, 71-80.

Hatough, A. \& Al-Eisawi, D.M. (1987) The Arabian oryx in Jordan. Journal of Arid Environments, 14, 291-300.

IUCN (2016) The IUCN Red List of Threatened Species 2016-3. Http:// www.iucnredlist.org [accessed 6 February 2017].

Kiwan, K., Boef, J. \& Boudari, A. (2001) Jordan. In Antelopes. Global Survey and Regional Action Plans. Part 4: North Africa, the Middle East and Asia (eds D.P. Mallon \& S.C. Kingswood), pp. 102-106. IUCN, Gland, Switzerland.

LAмв, R. (1984) Oryx runs wild in Jordan after sixty years in exile. World Wildlife News, 1983-1984 (Winter), 18-20.

Ministry Of Environment (2016) State of Jordan's Environment. Unpublished report. Ministry of Environment, Amman, Jordan. [In Arabic]

MOA (2015) Http://www.1jordan1.com/vb/archive/index.php/t129810.html [accessed 13 March 2017]. [In Arabic]

Nelson, B. (1973) Azraq: Desert Oasis. Allen Lane, London, UK.

Qumsiyen, M.B. (1996) Mammals of the Holy Land. Texas Technical University Press, Lubbock, USA.

Qumsiyen, M.B., Amr, Z.S. \& Budairi, A.M. (1996) Status and conservation of Artiodactyla (Mammalia) in Jordan. Mammalia, 6o, 417-430.

Qumsiyeh, M.B., Amr, Z.S. \& Shafei, D. (1994) The status and conservation of carnivores in Jordan. Mammalia, 57, 55-62.

Stutzman, F. (2006) An evaluation of identity-sharing behavior in social network communities. Journal of the International Digital Media and Arts Association, 3, 10-18.

RSCN (The Royal Society For The Conservation Of NAtURE) (2005) National Hunting Report. Unpublished report. RSCN, Amman, Jordan.

\section{Biographical sketches}

Енав EID has worked in biodiversity conservation for more than 15 years. He is currently the programme director at the Royal Marine Conservation Society of Jordan, and has previously worked as the head of research and survey at the Royal Society for the Conservation of Nature. His major interests are in mammals, reptiles and amphibians. RAMZI HANDAL is the head and founder of Jordan's Outdoor Sport Association, and his main interests are to conserve Jordan's biodiversity from illegal hunting and to contribute to reintroduction programmes for threatened species. 